\title{
Ethnic Violence and Conflict: The Dynamics of Ibn Khaldun's Theory of Asabiyyah (Social Feeling)
}

\section{Etnik Şiddet ve Çatışma: Ibn Haldun'un Asabiyet (Sosyal Duygu) Teorisi}

\author{
Mohd Yaseen Gada \\ Aligarh Muslim University, India \\ myyaseenm2@gmail.com
}

\begin{abstract}
What drives social change toward conflict? This is probably the main challenge in addressing what nurtures intra-state conflicts, and why sub-groups rebel and claim a separatist identity and politics in the pursuit of some ethnocentric needs. Throughout history, ethnic conflicts have long been a component of international politics. Even today, ethnic wars continue to be the most common form of armed conflicts around the world. The challenge of modernisation produces alienation which the ethnic groups are ill-prepared to withstand. Challenges to sociocultural and political ties, values, orientations, institutions and hierarchical social order is often viewed or perceived by the elite of these ethnic groups as threats to identity. Moreover, the intensive and extensive competition created by modernisation generates social frustration and anger leading to social conflict and violence. In this backboard, Ibn Khaldun's theory of 'Asabiyyah (social feeling) plays a vital role understanding the social bondage of these ethnic groups. He explained how this complex term encompasses both the cohesive force of the group, the conscience that it has its own specificity and collective aspirations, and the tensions that animate it ineluctably to seek power. Accordingly, 'Asabiyyah is what puts social groups on hegemonic Steroids, and makes individuals feel powerful at a particular point in time. The paper attempts to explore and examine the contemporary ethnic conflicts and violence through Ibn Khaldun's theory of social feeling. It concludes that any cultural, social, political threat to an ethnic group leads to conflict. It advocates that providing proper democratic space and representation of ethnic groups in decision making and policy forming bodies would reduce the ethnic tensions.
\end{abstract}

Keywords: Ethnic, Conflict, Asabiyyah, Ibn Khaldun, Social, Group, Feeling

Özet: Toplumsal değişimi çatışmaya iten şey nedir? Bu muhtemelen devlet içi çatışmaları neyin beslediğinin ele alınmasında ana zorluktur. Neden bazı gruplar bazı etnosentrik ihtiyaçların peşinde koşarken ayrılıkçı bir kimlik ve politika iddia ediyorlar? Tarih boyunca, etnik çatışmalar uzun zamandan beri uluslararası politikanın bir bileşeni olmuştur. Bugün bile, etnik savaşlar dünyadaki en yaygın silahlı çatışmalar biçimi olmaya devam ediyor. Modernleşme mücadelesi, etnik grupları dayanmaya hazır olmadıkları yabancılaşmaya itiyor. Sosyo-kültürel ve politik bağlara, değerlere, yönelimlere, kurumlara ve hiyerarşik sosyal düzene meydan okumalar, bu etnik 
grupların seçkinleri tarafından kimliğe tehdit olarak algılanmaktadır. Dahası, modernleşmenin yarattığı yoğun ve kapsamlı rekabet, sosyal hayal kırıklığı, toplumsal çatışma ve şiddete yol açan öfke yaratmaktadır. Arka planda, Ibn Haldun'un "Asabiyyah (birliktelik)" kuramı, bu etnik grupların toplumsal köleliğini anlamada hayati bir rol oynamaktadır. Bu karmaşık terimin hem grubun birleştirici gücünü, hem de kendi özgünlügüne ve ortak özlemlerine sahip olduğu bilincini kaçınılmaz bir şekilde güç arayışı uyandıran gerginlikleri kapsadığını açıklamaktadır. Buna göre, "Asabiyyah", sosyal grupları hegemonik steroidler üzerine yerleştiren ve bireylerin belirli bir zamanda kendilerini güçlü hissetmelerini sağlayan şeydir. Bu makale, çağdaş etnik çatışmaları ve şiddeti Ibn Khaldun'un asabiyet (birliktelik) teorisi ile keşfetmeye ve incelemeye çalışmaktadır. Herhangi bir kültürel, sosyal, politik tehdidin çatışmaya yol açtığı sonucuna varmaktadır. Karar vermede ve politika oluşturma organlarında uygun demokratik alan ve etnik grupların temsil edilmesinin etnik gerilim/eri azaltacağını savunulmaktadır.

Anahtar Kelimeler: Etnik, Çatışma, Asabiyet, Ibn Haldun, Sosyal Grup, Duygu

\section{Introduction}

The vast majority of contemporary societies are multiethnic and multicultural. Out of some 193 nation states listed in official sources, 150 such states have four or more ethnic groups within their boundaries. Most of these are increasingly confronted with minority groups demanding recognition of their identity and accommodation of their cultural differences. In a survey of such groups, Ted Gurr in his study in 1993 singled out 233 minority ethnic groups who are at "risk". By this he meant groups that, in the post-World War II period, have either taken political action on behalf of their collective discrimination or both. Hence they are actually or potentially engaged in inter-ethnic conflict. Of these 233 groups, only 27 , or about 12 percent have no record of political organisation, protest, rebellion or other form of inter-communal conflict since 1945. Gurr also pointed out that, out of 127 countries in the world that he examined, 75 percent had at least one, and many had more, highly politicised minorities (Gurr, 1993, $3-4)$. As such ethnic tensions and movements have become a major source of violent and non-violent conflicts. If around the world, so many multiethnic states are in trouble, it is obvious that there is a need to understand the causes behind these movements and their nature and type. Such an understanding can also help in looking for means and mechanisms for conflict resolutions. Moreover, large-scale ethnic violence is an interesting and important topic both because of the enormous human suffering it causes and because it could be an important piece of evidence in the larger puzzle of how world politics and polities are now evolving. In view of the fact that the prospect for peace and war, the maintenance of national unity and the fundamental human rights in many parts of the world and in many ways depend on the adequate solution of ethnic tensions the way States deal with the question has become one of the most important political issues 
in the contemporary world. A large number of scholars over the world are undertaking such studies. In this paper we will have a look at these. More importantly, this paper will offer a unique approach to examine and explore social problems by drawing on the method of the famous Arab philosopher, sociologist, historian, of the fourteenth century, Ibn Khaldun (AD 1332-1406).

The dynamics and relevance of Ibn Khaldun's study and understanding of societies represent a pattern in the changes that occur in man's political and social organisation. To the question: What causes differences in the size, quality, and influence of different human social organisations? Ibn Khaldun replies that there must be some factor, some incitement, for the desire for co-operation to exist on a large scale among some human beings than among others. Only thus can be large and powerful states have originated. This factor he calls 'Asabiyyah' or "solidarity", "group feeling", "group consciousness", a term which he borrowed from classical usage and to which he gave a new, positive meaning (Rosenthal, 1967: xi). Before we explore Ibn Khaldun's understanding of what drives social change towards conflict, it is essential to understand the concept of "ethnicity", and how it can be related with the "group feeling" having common traits and customs.

\section{Ethnicity}

Ethnicity is a contested and complex concept that is historically, socially and contextually based. The social relations are dynamic; their meaning changes overtime. Apple (1993: viii) refers to them as "place markers" operating in a complex political and social arena.

Historically, the term "ethnic" derives from the Greek ethnos which refers to Heathen nations or peoples not converted to Christianity. It was also used to refer to races or large groups of people having common traits and customs or to exotic primitive groups. In anthropological literature the term "ethnic group" is generally used to designate a population which (1) is largely biologically self perpetuating (2) shares fundamental cultural values, realised in overt unity in cultural forms; (3) makes up a field of communication and interaction; (4) has a membership which identifies itself, and is identified by others as constituting a category distinguishable from other categories of the same order (Narang, 1995: 1-15). By ethnic group sociologists generally mean a relatively stable sociocultural unit performing an unspecified number of functions, bound together by a language, often linked to a territory, and derived actually or allegedly from a system of kinship. In this sense the ethnic community is an extremely old collective reality. International Encyclopaedia of Social Sciences defines an ethnic group as "a distinct 
category of the population in a larger society whose culture is usually different from its own. The members of such a group are, or feel themselves, or are thought to be, bound together by common ties of race or nationality or culture" (Sills, 1979: 167).

In modern political usage the term "ethnic" is generally used as a designation of social unity based upon common and separate language or dialect, historical living in a defined area, occupation and mode of life, cultural and social traditions, customs and folklore. It is also used for social class, racial or national minority groups and also for distinguishing cultural and social groups in society. To put it in other words, generally ethnicity is considered as the mobilisation of a group of people who share common attributes in terms of culture, language, religion, history, etc., and who are different from another group which also shares certain common attributes. This mobilisation can be on a single attribute or more. For example mobilisation on the basis of language, religion (known as communalism in the Indian context), language, caste or tribe is considered as ethnic mobilisation. Paul R. Brass is one of the examples who uses the ethnic mobilisation and the communal mobilisation interchangeably (Brass, 1974). Dipankar Gupta differentiates between the ethnicity and communalism. He argues that ethnicity necessarily denotes mobilisation of a group in relation to another with reference to the nation-state-the territory and the sovereignty (Gupta, 1997). An ethnic group either proclaims itself to be the real adherent of the faith in the territory of a nation or wants to set up a sovereign state or questions the loyalty of another group.

From the above it becomes clear that in the present day context those groups which, in given social context, consciously choose to emphasise their most meaningful primary, extra familial identity on the basis of religious, racial, cultural, linguistic, national characteristics, or a combination of any of them, are referred to as ethnic groups.

The situation is particularly significant in numerous new states that have achieved independence since the Second World War i.e. the post-colonial states in Asia, Africa and the Caribbean. In most of the multi-ethnic states the world over, in recent years, there has been a resurgence of ethnic and cultural demands and group consciousness which is generally referred to as rise of ethnicity.

\section{Ethnic Conflict and 'Asabiyyah}

As has already been mentioned above, ethnic consciousness and conflicts are pervasive around the world. Pakistan, the Soviet Union, Yugoslavia and Chezchoslovakia have already been disintegrated. 
What drives these ethnic consciousness and conflicts can be explained in Ibn Khaldun's theory of 'Asabiyyah. The theory of "Asabiyyah" (meaning: 'tribalism', 'clanism', or in a modern context 'nationalism') is one of the best known aspects of the Muqaddimah.

According to the Arab-English Lexicon, the word 'Asabiyyah emerged from the word "ta'asub" which literally means "...bounding the turban round (his own) head". 'Asabiyyah is explained as the:

"...quality of an individual who is possessing 'Asabiyyah which refers to th action of ones in helping his people or his group against any aggressive action, the quality of a person who is angry for the sake of his group and protecting them, the action of ones who invites others to help his group, to combine or league with them in facing those who act hostility towards them whether they are wrongdoers or wronged, the action of an individual who associate with others or of him who protects others or partisanship and a strong association with holds numbers of person closely bound based on the same interest and opinion..." (Lane, 1984: 2059).

Interestingly, the term 'Asabiyyah used by Ibn Khaldun in his theory of social development has been translated in various ways by recent scholars. For instance, Rosenthal has interpreted 'Asabiyyah as "group feeling", which according to Lacoste is the closest meaning to this term (Lacoste, 1984: 99). Similarly, Mahdi views that 'solidarity' is the nearest meaning of 'Asabiyyah which was also used by Gumplawicz and Issawi (Mahdi, 1957). However, some of the modern scholars have preferred to use the Arabic term without translating it, while others have defined 'Asabiyyah as "sense of solidarity, group feeling, group loyalty and esprit de corps" (Rabi', 1967: 49).

Through his historical experience and meticulous understanding, Ibn Khaldun points that whenever there would arise any threat or difficulties to any social group, they would protect their social bond in whatever ways. Thus, based on Ibn Khaldun's explanation, the spirit of 'Asabiyyah basically exists due to the primitive life possessed by certain groups or nations when they face difficulties or threats. These force them to stand together to protect themselves and their fellows from any danger outside their group. The spirit of group feeling or 'Asabiyyah emerged because they had to fight for their basic need. The spirit of 'Asabiyyah does not necessarily arise from the blood relationship, but have a common view from "...alliance or client (-master) relationship" (Rosenthal, 1967: 100). 


\section{Explaining Ethnic Violence}

Now let us turn to the main part of our discussion: What drives social change toward conflict? This is probably the main challenge in addressing what nurtures intra-state conflicts, and why sub-groups rebel and claim a separatist identity and politics in the pursuit of some ethnocentric needs. In the post-Weberan period, the main question remains about how to "interpret the meaning of social action and thereby give a casual explanation of the way in which the action proceeds and the effects which it produces" (Cherkaoui, 2010). Until now, scholars and theorists have found partial answers only, and have not successful answering the whole problem. This reduces the multi- and inter-disciplinary claim of Conflict Resolution with complex conflicts.

Tajfel's theory of extreme ("social mobility" to "social change"); Parsons's theory of Social Systems; Carl Schmitt's theory of the "supremacy" of the "Political"; Giddens's structuration theory, to name a few, provide unsatisfactory and/or partial explanation of the social change (Cherkaoui, 201).

As a reflexive thinker, wandering along the Mediterranean to explore "umran"-a new and independent "science" of society within the broader field of philosophical inquiry, Ibn Khaldun was reflecting on his dynamical systems theory of societies with a trajectory of their social, economic, and political decline. In other words, Ibn Khaldun sought nothing less than to discover and explain the basic laws and principles upon which all of human society operated. This theory is of course 'Asabiyyah.

Although, 'Asabiyyah was a familiar term in the pre-Islamic era; but it became popularized in Khaldun's Muqaddimah (Introduction) where it is described as the fundamental bond of human society and the basic motive force of history. Ibn Khaldun understood 'Asabiyyah in much more dynamic terms. Ibn Khaldun uses the term 'Asabiyyah to describe the bond of cohesion among humans in a group forming community. The bond, 'Asabiyyah, exists at any level of civilization, from nomadic society to states and empires. 'Asabiyyah is most strong in the nomadic phase, and decreases as civilization advances. As this 'Asabiyyah declines, another more compelling 'Asabiyyah may take its place. Thus, civilizations rise and fall, and history describes these cycles of 'Asabiyyah as they play out.

Ibn Khaldun's theories, as mentioned earlier, were based on his experience and his study of politics in the Mahgreb, where Berber nomads often swept out the desert to conquer 
sedentary kingdoms, established themselves as rulers there, and were then in turn swept away by the next incursion from the wilds. Central to this cyclical vision of politics is the distinction Ibn Khaldun makes between Umran, or "civilization", and Budawah, or "the Bedouins". Ibn Khaldun campares the lives or cultures of civilized people ("Umran Hadari) in the city with the life of the Bedouin ('Umran Badawi) and tried to establish a relation between the two (Rosenthal, 1967: 91-122). He asserts that 'Asabiyyah importance within the tribal unit is not exclusive, but its application goes far beyond mere tribal life and is of an almost universal validity. Interestingly, Ibn Khaldun introduces 'Asabiyyah first in familial terms:

"Their [the Bedouins] defense and protection are successful only if they are a closely knit group of common descent. This strengthens their stamina and makes them feared, since everybody's affection for his family and his group is more important (than anything else). Compassion and affection for one's blood relations and relatives exists in human nature as something God put into the hearts of men. It makes for mutual support and air, and increase the fear felt by the enemy. Those who have no one of their own lineage...cannot live in the desert, because they would fall prey to any nation that might want to swallow them up." (Rosenthal, (1967, 97-98).

Mutual cooperation and kinship among these clans will naturally lead to a strong 'Asabiyyah. However, Ibn Khaldun also states that it is not necessary that common descent itself makes 'Asabiyyah possible. However, if different communities are tightknitted in a common environment and circumstance would also lead a strong 'Asabiyyah. He states:

"The consequences of common descent, though natural, still are something imaginary. The real thing to bring about the feeling of close contact is social intercourse, friendly association, long familiarity, and the companionship that results from growing up together having the same wet nurse, and sharing the other circumstances of life and death. If close contact is established in such a manner, the result will be affection and cooperation." (Rosenthal, 1967: 148).

Some scholars view that Ibn Khaldun's 'Asabiyyah illustrates a willingness to die for an individual of a group. Therefore, it is maintained that "unless individuals are prepared to die for their group, the group itself will die" (Green, 2015). However, 'Asabiyyah does not end there: 
"Once group feeling [ 'Asabiyyah] has established superiority over the people who share in that particular 'Asabiyyah, it will, by its very nature, seek superiority over people of other 'Asabiyyah unrelated to the first. If the one 'Asabiyyah is the equal of the other or is able to stave off its challenge, the competing people are even with and equal to each other. Each 'Asabiyyah maintains its own domain and people, as is the case with tribes and nations all over the Earth. However, if the one 'Asabiyyah overpowers the other and makes it subservient to itself, the two 'Asabiyyah enter into close contact, and the defeated 'Asabiyyah gives added power to the victorious one, which, as a result, sets it goal of domination and superiority higher than at first." (Rosenthal, 1967: 108).

What is the key point here is to note that those who have been allowed to join the conquering host slowly start to feel it's 'Asabiyyah be subsumed as the two groups "enter into close contact," sharing the same trials, foods, circumstances, and becoming acquainted with the others' customs, but just as importantly, sharing the same set of incentives. Once the losers are forced together with the winners, defeat for the main clan is defeat for all; glory for the main clan is glory for all; booty gained by the main clan's conquests becomes booty to be shared with all. Once people from a subordinate group begin to feel like the rise and fall of their own fortunes is inextricably linked to the fate of the group that overpowered them then they become willing to sacrifice and die for the sake of this group, for it has become their group (Green, 2015).

Moreover, religion also plays a crucial role in binding the members of a group through the spirit of 'Asabiyyah. The spirit of 'Asabiyyah is essential in spreading the teaching of a religion. Religion eliminates jealousy and imparts fellow being among the members of a group that possesses 'Asabiyyah. In Rosenthal's words, “...religion is the most powerful cement that can hold together a large sedentary people..." (Halim, et. al., 2012: 1234). In addition, having a common sense of religion allows the members of a group to work together, "to the extent of being willing to die to achieve the objectives that they believe in. Accordingly, the physical aspect of hardship and the spiritual aspect which is the element of religion actually uphold a strong group feeling or 'Asabiyyah in developing their group or nation" (Halim, ibid). Ibn Khaldun also describes that having achieved a large mass of people, there should be some form hierarchy to run and coordinate their actions and leadership to resolve inner disputes. As such, it is the nature of the leader of the moment to try and make his authority permanent-a type of authority that Ibn Khaldun calls mulk.

Rosenthal translates mulk as "royal authority," Isawii translates it as "sovereignty," Baali uses "state," and Goodman uses "kingdom." However, Ibn Khaldun has distinguished 
between royal authority or mulk and leadership. He noted that this power is different from which most clan chieftains or nomadic leaders possess:

"Human beings need someone to act as a restraining influence and mediator in every social organization, in order to keep members from fighting with each other. That person must, by necessity, have superiority over the others in the matter of group feeling ['Asabiyyah].... Such superiority is royal authority (mulk). It is more than leadership. Leadership means being a chieftain, and the leader is obeyed, but he has no power to force others to accept his rulings. Royal authority means superiority and the power to rule by force [if necessary]." (Rosenthal, 1967: 108).

The increase in power of royal authority increases the incentives of his warriors, clansmen, and adherents face begin to change. Thus he writes:

"First, as we have stated, the royal authority, by its very nature, must claim all glory for itself. As long as glory was the common property of the group, and all members of the group made an identical effort (to obtain glory), their aspirations to gain the upper hand over others and to defend their own possessions were expressed in exemplary unruliness and lack of restraint. They all aimed at fame. Therefore, they considered death encountered in pursuit of glory, sweet, and they preferred annihilation to the loss of it. Now, however, when one claims all glory for himself, he treats the others severely and holds them in check. Further, he excludes them from possessing property and appropriates it for himself. People become too lazy to care for fame. They become dispirited and come to love humbleness and servitude." (Rosenthal, 1067: 133).

This is the nucleus of the 'Asabiyyah cycle Ibn Khaldun is famous for. Though Islam generally condemns 'Asabiyyah: "a blind support for one's group without regard for the justice of its cause" (Rabi, 1967: 49-50). As such, any show of 'Asabiyyah is deprecated as an atavistic survival of the pagan, pre-Islamic mentality. However, Ibn Khaldun was, of course, aware of this negative interpretation; but he distinguishes between his objectionable form and the natural 'Asabiyyah that is a part of being human. The latter is the affection one feels for others when they are treated unjustly or killed. Nothing can take it away. This form of 'Asabiyyah is not forbidden by Muslim religious law (Irving, 2007: 17).

Ibn Khaldun emphasises that only tribes held together by group feeling and loyalty can live in the desert. They have to be united because they are in a state of conflict, actual or potential, with other tribes due to the scarcity of pasture and water. Group feeling 
results from "blood" ties, or something corresponding to it-the notion or fact of common descent. The advantage of such a notion or fact consists in the group feeling or solidarity that derives from it, and which leads to mutual affection, devotion, and aid-and unity against hostile external forces or difficulties.

In this background we can explain and understand the contemporary ethnic conflict and violence. Any deprivation to the ethnic groups could drive consciousness at par with 'Asabiyyah that would lead conflict. Therefore, the old paradigm that predicted that factors inherent in modernization including economic development, urbanization, growing rates of literacy and education as well as advancements in science and technology, would inevitably lead to the demise of the role of ethnicity, religion or culture in politics, stands changed.

\section{Modernisation and Ethnicity}

Modernisation means the attainment of relatively higher levels of variables, such as "education, per capita income, urbanisation, political participation, industrial employment, media participation" (Robert. 1973: 152). As stated, in early modernising theory, ethnic identity referred to traditional obstacles which were supposed to disappear in the course of development. However, David Brown argues that the experience of the last decades has shown that these theories of progressive integration of peoples were seriously flawed. While, to begin with, there was such developments and modernisation brought in uniformity but in the course of time, it threw up its own contradictions and divergent elements, of which national minorities were a principal expression, both in already developed and newly developing societies (Brown, 2000: 1025; Payne and Nassar, 2016).

Moreover, the colonial period had brought about a high degree of politico-territorial integration through an efficient, centralised way, coercive machinery of the government. However it also helped cultural and ethnic groups organise themselves politically. The nationalist movement also mobilised ethnic groups, both strategically and ideologically. The notion of self-determination, the prime mover of independence movements in the colonies, derived from the concept of freedom as much as it did from the conception of nation as a definable unit of a people with a common political "will" of forming a sovereign state of their own. But after independence various sectional groups sought due recognition. Thus modernisation, both in developed and developing societies, is inter alia a source of aggravation of aggravating stratificational inequalities, alienation of the individual and groups. Walker Connor points out that the available evidence about 
the pattern of ethnic dissonance in the world, at various levels of modernisation, indicates that material increase in social communication and mobilisation intensifies cultural awareness and exacerbates interethnic conflict (Connor, 1994: 37).

Thus modernization leads to the strengthening of primordial community based ties. Modernisation sharpens differentiation, articulates group identity consciousness, and produces intra-group and inter-group competition which often results into ethnic conflict and violence.

\subsection{Fear of Assimilation and Homogenisation}

Ethnic groups feared assimilation and homogenisation of their distinct culture and identities by the majority/dominating community/group both regional as well as national. To counter such a possibility they articulated their demand for territoriality based on their distinctiveness to safeguard their identity (Salih, 2003: 115).

\subsection{Fear of Marginalisation}

Another cause of identity consciousness among the different ethnic groups/communities is the fear of marginalisation, because of the domination of an out group/community over the indigenous people. As Morten Boas notes, an out-community is one, which lacks a historical linkage with the territory they inhabit along with the indigenous people but become a part of it due to the voluntary migration or state sponsored project of demographic engineering (Boas, 2015: xv).. In this situation, intercommunity competition becomes inevitable because it threatens the interests of the indigenous community.

\subsection{Fear of Deprivation and Discrimination}

Modernisation has also produced political and economic competition on an unprecedented scale whereby elite mobilise the members of their community to have due share in power and resources in competition with other groups. Denial of equality by the state in economic and political fields also creates a sense of discrimination and deprivation among the ethnic groups (Heath, et. al., 2013: 115). They have not got proper representation in national life and governmental institutions. It is perceived as internal colonialism by the victim community. Minority communities are always at the risk of deprivation in power, services and resources.

\subsection{Loss of Autonomy}


In the pre-colonial period, ethnic groups had small functional autonomous political entities. However, in the post-colonial era, this autonomous status of these communities came to an abrupt end. In the name of state-formation and to establish its complete sovereignty in its own territorial framework, the ruling elite started to take over centralisation of administration. Further the state imposed modern but majority oriented institutions over these communities at the cost of destruction of their own traditional natural and historical communal institutions. In such an atmosphere, as Ajay Patnaik writes, the autonomous life of the communities came to an end (Patnaik, 2016) which created a widespread discontent among ethnic groups especially among those which are small in size.

Therefore, the causes of the ethnic conflicts in the modern world can be understood through the concept social change as envisioned in Ibn Khaldun's theory of 'Asabiyyah. This concept seems to anticipate modern conceptions of social capitol arising in social groups, and contextualize social change in time, space, and human conscience. The core aspect of his theory involved the explanation of human cooperation and conflict. He wrote that men are incapable of complete self-subsistence as individuals.

\section{Conclusion}

The most obvious point to emerge from the above discussion is that it is important to understand ethnic violence by looking at a state-society relation through a structural analysis, which I argue is the most useful paradigm for studying these conflicts and problems. Thus, in his work on states and societies, Ibn Khaldun argues that the genealogy of the state and its structure can help explain its development and the way states treat their subjects. This structural paradigm helps explain ethnic violence by contextualizing its temporal, political, and materialist dimensions and addressing the weaknesses and limitations of the approaches. This framework contextualizes the policy of the nation-state toward its minority groups, native or non-native, through an analysis of the nature of the state and its historical development, taking into account which group were included and excluded from the national project at its origin. This focus helps ground the attitude of state's authorities toward those individuals or groups who are not included within the state's national agenda. In short, Ibn Khaldun's 'Asabiyyah calls for the study of social change between aging and emerging political actors. It offers the ost dynamic and complex perspective that is warranted by dynamic and complex conflicts. 


\section{References}

Apple, M. (1993). "Constructing the "Other": Rightist Reconstructions of Common Sense". In Cameron M. \& Warren C. (Eds.), Race, Identity and Representation in Education. New York: Routledge.

Boas, M. (2015). The Politics of Conflict Economies: Miners, Merchants and Warriors in the African Borderland. New York: Routledge.

Brass, P.R. (1974). Language, Religion and Politics in North India. London: Cambridge University Press.

Cherkaoui, Mohammed. (2010). "Conflict Resolution a la Asabiyyah: Ibn Khaldun is Back". Confrontations. Retrieved from http://scar.gmu.edu/magazine-article/conflict-resolution\%C3\%A0-la-Asabiyyah-ibn-khaldun-back.

Brown, D. (2000). "Ethnic Revival: perspectives on state and society". In John H. \& Anthony D. S. (Eds.), Nationalism: Critical Concepts in Political Science, Volume 3. London and New York: Routledge.

Connor, W. (1994). Ethnonationalism: The Quest for Understanding. Princeton: Princeton University Press.

Green, T. (2015). "Introducing 'Asabiyyah". Retrieved from http://scholarsstage.blogspot.in/2015/05/introducing-Asabiyyah.html.

Gupta, D. (1997). The Context of Ethnicity: Sikh Identity in a Comparative Perspective. New Delhi: Oxford University Press.

Gurr, T.R. (1993). Minorities at Risk: A Global View of Ethnopolitical Conflicts. Washington, D.C.: United States of Peace Press.

Halim, A.A., et. at. (2012). "Ibn Khaldun's Theory of Asabiyyah and its Application in Modern Muslim Society". Middle-East Journal of Scientific Research 11 (9): 1232-1237. DOI: 10.5829/idosi.mejsr.2012.11.09.227010.

Heath, et. al. (2013). The Political Integration of Ethnic Minorities in Britain. UK: Oxford University Press.

Irving, M.Z. (2007). The Historical Muhammad. UK: Polity Press

Lacoste, Y. (1984). Ibn Khaldun: The Birth of History and the Past of the Third World. London: Verso.

Lane, E.W. (1984). Arabic-English Lexicon. Vol. 2. Cambridge: Islamic Text Society Trust.

Mahdi, M. (1957). Ibn Khaldun's Philosophy of History. London: George Allen and Unwin Ltd.

Narang, A.S. (1995). Ethnic Identities and Federalism. Shimla: Indian Institute of Advanced Study. Rabi', M.M. (1967). The Political Theory of Ibn Khaldun. Leiden: E.J. Brill.

Patnaik, A. (2016). Central Asia: Geopolitics, security and stability. New York: Routledge.

Payne, R.J. and Nassar, J. (2016). Politics and Culture in the Developing World. New York: Routledge. 
Robert, H.B. (1973). "Modernisation, Ethnic Competition and Rationality of Politics in Contemporary Africa". In Donald R. \& Victor A. O. (Eds.), State versus Ethnic Claims: African Policy Delimmas. Boulder: Westview Press.

Rosenthal, F. (1967). Ibn Khaldun: The Muqadimmah - An Introduction of History, Abridged. London: Routledge and Kegan Paul.

Salih, R. (2003). Gender in Transnationalism: Home, Longing and Belonging among Moroccan Migrant Women. New York: Routledge.

Sills, D.L. (1979). International Encyclopedia of Social Sciences. David L. Sills, (Ed.). US: MacMillan Company and The Free Press. 